\title{
Effects of Two Hypocaloric Diets Supplemented With White Lupine or Oats on Lipid Peroxidation, Reverse Cholesterol Transport and Paraoxonase Activity in Obese Rat
}

\author{
Fatima Z. Chabane ${ }^{1}$, Sabrine Louala ${ }^{1}$, Nabila Boukhari ${ }^{1}$, Mounia Besbes ${ }^{1}$, Douja Taleb-Senouci ${ }^{1} \&$ Myriem Y. \\ Lamri-Senhadji $^{1}$ \\ ${ }^{1}$ Laboratory of Clinical and Metabolic Nutrition, Department of Biology, Nature and life Sciences Faculty, \\ University of Oran, 31100, Oran, Algeria \\ Correspondence: Myriem Y. Lamri-Senhadji, Laboratory of Clinical and Metabolic Nutrition, Department of \\ Biology, Nature and life Sciences Faculty, University of Oran, 31100, Oran, Algeria. Tel: 213-4158-1944; Fax: \\ 213-4156-0601. E-mail: mylamri@hotmail.fr
}

Received: July 5, 2013 Accepted: July 23, 2013 Online Published: August 1, 2013

doi:10.5539/jfr.v2n5p1 URL: http://dx.doi.org/10.5539/jfr.v2n5p1

\begin{abstract}
The purpose of this study was to compare the effects of two hypocaloric diets supplemented with legume or cereal on hyperglycemia, dyslipidemia, serum $\mathrm{HDL}_{2}$ and $\mathrm{HDL}_{3}$ composition, lipid peroxidation, and lecithin-cholesterol acyltransferase (LCAT) and paraoxonase (PON1) activities in obese rats. Obesity was induced by feeding a high-fat-diet during 3 months. At $400 \pm 20 \mathrm{~g}$, the obese rats were divided into three groups $(\mathrm{n}=8)$ : two groups were submitted for 28 days to a caloric restriction $(\mathrm{CR})$ at $0.9 \mathrm{MJ}$ supplemented with lupine (CR-Lupine group) or oats (CR-Oats group). The third group was fed a caloric restricted diet without supplementation (CR group). At day 28, glycemia was lower (-21\%) in the CR-Oats than the CR group. CR-Oats diet reduced total cholesterol content (-13\%) when compared to lupine supplementation. In contrast, CR-Lupine diet decreased serum triacylglycerols by $22 \%$ and $15 \%$ respectively versus $\mathrm{CR}-$ Oats and CR diets. Lipoproteins lipid peroxidation was significantly lower in CR-Lupine and CR-Oats when compared to the CR diet. Serum PON1 activity was increased in CR-Lupine (+88\%) and CR-Oats $(+82 \%)$ groups compared to CR group. Furthermore, LCAT activity was enhanced in CR- Lupine ( $+23 \%$ and $+26 \%$, respectively) versus CR and CR-Oats groups. In obese rats, caloric restriction supplemented with lupine compared to oats supplementation has beneficial effect on hypertriglyceridemia and improves reverse cholesterol transport by enhancing LCAT activity leading to anti-atherogenic effects. This effect is partially reinforced by the high HDL PON1 activity which protects it from oxidation.
\end{abstract}

Keywords: hypocaloric diet, lupine, LCAT, oats, obesity, PON1

\section{Introduction}

The international association for the study of obesity has determined that approximately 1.5 billion adults are either overweight or obese, with almost 500 million being obese (International Obesity Taskforce, 2012). Consequently, obesity is a world problem of public health which associated with much comorbidity, such as arterial hypertension, type 2 diabetes, dyslipidemia, cardiovascular diseases (CVD) and certain cancers (Hebert, Allison, Archer, Lavie, \& Blair, 2013). Recently, the caloric intakes were designated as a major responsible of the overweight of the modern populations (Venn et al., 2013).

In rats, the consumption of hypercaloric diets induced obesity by increasing lipids storage (Festuccia, Laplante, Berthiaume, Gélinas, \& Deshaies, 2006) which are essentially directed to the adipose tissue (Bergouignan, Blanc, \& Simon, 2010). Obesity is associated with many deleterious changes of lipid metabolism: increased low-density lipoprotein cholesterol (LDL-C), very low-density lipoprotein cholesterol (VLDL-C), triacylglycerols (TG) and reduced high density lipoprotein cholesterol (HDL-C) concentrations (Poirier et al., 2006).

HDL plays an important protective role against atherosclerosis and CVD. The anti-atherogenic properties of HDL include the promotion of cellular cholesterol efflux and reverse cholesterol transport (RCT), as well as antioxidant, anti-inflammatory and anti-coagulant effects (Bergouignan, Blanc, \& Simon, 2010). 
Lecithin-cholesterol acyltransferase (LCAT, EC 2.3.1.43) is a 63-kDa glycoprotein produced exclusively in the liver. This plasma enzyme circulates in association with $\mathrm{HDL}$, in particular $\mathrm{HDL}_{3}$. It esterifies unesterified cholesterol (UC) to cholesteryl ester (CE) and requires for its activity the apolipoprotein (apo) A-1, cofactor -activator (Bazzano, Thompson, Tees, Nguyen, \& Winham, 2009; Rossmeislová, Mališová, Kračmerová, \& Stich, 2012). Paraoxonase 1 (PON1) is also an enzyme associated with HDL and is implied in the antioxidant capacity of this lipoprotein (Baudet, Daugareil, \& Ferrieres, 2011).

The US Department of Agriculture recommends strategies that include both overall caloric restriction and increased physical activity for weight loss (Wells, \& Buzby, 2005). Hypocaloric diet is a basic tool of the weight reducing treatment of obesity and its related disorders (Martínez-Villaluenga, Frías, \& Vidal-Valverde, 2011). Low caloric diets are often balanced with legumes supplementation because of their high protein content (ranged from $18 \%-45 \%$ ), soluble fiber and other bioactive compounds (Maki et al., 2011) or with cereals for their richness in several nutrients and phytochemicals (Archer, Johnson, Devereux, \& Baxter, 2004). Legumes and cereals incorporation into a weight loss program diet can be strategically effective in improving lipid profile (Podrez, 2010). Lupine proteins compared to casein slightly lowered the concentration of LDL-C in hypercholesterolemic subjects, without altering HDL-C (Dullaart et al., 2010). The incorporation of lupine in the diet increases postprandial satiety 4 to 5 hours and lowers energy intake by $15 \%$ on the day of nutritional intervention (Archer, Johnson, Devereux, \& Baxter, 2004). The choice of lupine is because this legume been little studied compared to other legumes such as soybeans and chickpeas. Similarly, oats, a whole grain cereal, has been little investigated compared to other cereals (wheat bran). In this context, the aim of this study was to determine the effects of two hypocaloric diets supplemented with white lupine or oats on hyperglycemia, dyslipidemia, lipid peroxidation, serum $\mathrm{HDL}_{2}$ and $\mathrm{HDL}_{3}$ compositions and lecithin-cholesterol acyltransferase (LCAT) and paraoxonase (PON1) activities in Wistar rats fed a high-fat diet.

\section{Materials and Methods}

\subsection{Animals and Diets}

Male Wistar rats (Iffa Credo, l'Arbresle, Lyon, France) $(\mathrm{n}=24)$, weighing $120 \pm 10 \mathrm{~g}$ were housed in stainless steel cages at $23 \pm 1{ }^{\circ} \mathrm{C}$ and $55 \pm 5 \% \mathrm{RH}$ with a 12-hour light/dark cycle. Obesity was induced by a high-fat-diet ( $20 \%$ mutton fat) during three months. After this period, obese rats (body weight $(\mathrm{BW})=400 \pm 20$ $\mathrm{g}$, serum glucose concentrations $=11 \pm 0.6 \mathrm{mmol} \mathrm{L}^{-1}$, total cholesterol $(\mathrm{TC})=2.8 \pm 0.6 \mathrm{mmol} \mathrm{L}^{-1}$ and triacylglycerols $\left.(\mathrm{TG})=1.34 \pm 0.05 \mathrm{mmol} \mathrm{L}^{-1}\right)$ were divided into three experimental groups $(\mathrm{n}=8)$ : two groups were submitted for 4 weeks to a caloric restriction (CR) at $0.9 \mathrm{MJ}$ ( $40 \%$ of a standard diet) supplemented with legumes $(22 \% \mathrm{w} / \mathrm{w}$ white lupine) (CR-Lupine group) or cereals $(20 \% \mathrm{w} / \mathrm{w}$ oats) (CR-Oats group). The third group was submitted to a CR without supplementation (CR group). Food and tap water were provided ad libitum. BW was recorded weekly. The general guidelines for the care and use of laboratory animals recommended by the Council of European Communities (1986) were followed and the protocol and use of rats were approved by our institutional committee on animal care and use.

\subsection{Blood Samples}

At day 28 , eight rats from each group were anesthetized with sodium pentobarbital (60 mg/kg BW). Blood was collected from the abdominal aorta into dried tubes and serum was prepared by low-speed centrifugation at $1,000 \mathrm{~g}$ for $20 \mathrm{~min}$ at $4{ }^{\circ} \mathrm{C}$. A serum aliquot was preserved in tubes containing $0.1 \% \mathrm{w} / \mathrm{v} \mathrm{Na} \mathrm{NDDTA}_{2}$ and $0.02 \%$ w/v sodium azide for biological parameters and lipoproteins assays and another aliquot was used to measure LCAT and PON1 activities.

\subsection{Glycemia and Serum Lipids Concentrations Analysis}

Glycemia was measured by strips test (ACCU-CHEK Active, Germany). Serum TC and TG concentrations were estimated by enzymatic colorimetric methods (kits GPO-POD Sprinreact, Spain).

\subsection{Isolation of Serum Lipoproteins Fractions}

Serum VLDL and LDL-HDL ${ }_{1}$ were isolated by precipitation (Burstein, Scholnick, \& Morfin, 1970) using $\mathrm{MgCl}_{2}$ and phosphotungstate (Sigma Chemical Company, France). $\mathrm{HDL}_{2}$ and $\mathrm{HDL}_{3}$ were separated by precipitation (Burstein, Fine, Atger, Wirbel, \& Girard-Globa, 1989) using $\mathrm{MgCl}_{2}$ and dextran sulfate weight 500,000 (Sigma Chemical Company, France).

\subsection{Serum and Lipoproteins Lipid Peroxidation Measurement}

Lipid peroxidation in serum and lipoproteins was estimated by measuring thiobarbituric acid reactive substances (TBARS) concentrations (Quintanilha, Packer, Szyszlo, Racanelly, \& Davies, 1982) using tetraethoxypropane 
(Prolabo, Fontenay sous bois, France) as a precursor of malondialdehyde (MDA), the principal marker of free radicals determination, which reacts in acid medium and hot with two molecules of thiobarbituric acid (TBA) to give a pink colored complex which absorbs at $532 \mathrm{~nm}$.

\subsection{Characterization of Serum $H D L_{2}$ and $H D L_{3}$ Fractions}

In $\mathrm{HDL}_{3}$ fraction TC was determined as described previously. Unesterified cholesterol (UC) was evaluated by enzymatic method (kit CHOD-PAP Biolabo, France). Esterified cholesterol (EC) levels were calculated from the difference between TC and UC. Cholesteryl esters (CE) amounts were estimated as 1.67 times the EC amounts. Phospholipids (PL) were evaluated by enzymatic method (kit CHO-POD Cypress, Belgium). Protein contents were estimated using bovine serum albumin as a standard (Lowry, Rosebrough, Farr, \& Randall, 1951). $\mathrm{HDL}_{2}-\mathrm{CE}$ were estimated as described previously.

\subsection{Assay for LCAT Activity}

LCAT activity was determined on fresh serum by an endogenous method (Albers, Chen, \& Lacko, 1986). This procedure was based on the disappearance of the molecules of UC which are transformed into EC after 4 hours of incubation at $37^{\circ} \mathrm{C}$, starting from a fatty acid and lecithin. UC was evaluated by the method described previously. The cholesterol esterifying activity was expressed as nanomoles of esterified cholesterol h-1 $\mathrm{mL}^{-1}$ of serum.

\subsection{Assay for PON1 Activity}

Paraoxonase activity measurement was performed in the absence (basal activity) and presence of $\mathrm{NaCl}$ (salt-stimulated activity). The rate of paraoxon hydrolysis (diethyl- $p$-nitrophenylphosphate) was measured by monitoring the increase of absorbance at $270 \mathrm{~nm}$ and $25^{\circ} \mathrm{C}$. For this assay, $10 \mu \mathrm{L}$ of sample was added to $1 \mathrm{~mL}$ of a solution containing $10 \mathrm{mM}$ of phenyl acetate in $20 \mathrm{mM}$ Tris/ $\mathrm{HCl} \mathrm{pH} 8.0$ and $1 \mathrm{mM} \mathrm{CaCl}_{2}$. The activity was calculated relative to the molecular extinction coefficient of the phenyl $\left(1310 \mathrm{M}^{-1} \mathrm{~cm}^{-1}\right)(\mathrm{Kuo}, \& \mathrm{La} \mathrm{Du}, 1995)$.

\subsection{Statistical Analysis}

Values are given as means \pm S.E.M. of eight rats per group. Statistical evaluation of the data was carried out by STATISTICA (Version 5, 1, Statsoft, Tulsa, OK, USA). After analysis of variance (ANOVA), the classification of the means was performed using Duncan's new multiple range test (Duncan, 2007). The means with different superscript letters $(a, b, c)$ were considered significantly different $(\mathrm{P}<0.05)$.

\section{Results}

\subsection{Body Weight, Glycemia and Serum Lipids}

At day $28, \mathrm{CR}, \mathrm{CR}-\mathrm{Lupine}$ and CR-Oats diets induced a reduction in body weight (BW) $(-10 \%,-13 \%$ and $-9 \%$, respectively), serum glucose concentration $(-43 \%,-50 \%,-55 \%$, respectively), TC levels $(-56 \%,-46 \%,-54 \%$, respectively) and TG concentrations $(-39 \%,-48 \%,-33 \%$, respectively) when compared with baseline values (day $0)$.

At day 28, BW was similar in the three groups (Table 1). Glycemia showed no significant difference in CR-Lupine compared to the CR-Oats and CR group. However, serum glucose concentration was lower (-21\%) in the CR-Oats group than the CR group.

Table 1. Body weight (BW), glycemia and serum total cholesterol (TC) and triacylglycerols (TG) concentrations of rats fed experimental diets for 28 days

\begin{tabular}{lccc}
\hline & CR & CR-Lupine & CR-Oats \\
\hline BW $(\mathrm{g})$ & $360 \pm 20$ & $350 \pm 1$ & $366 \pm 10$ \\
Glycemia $\left(\mathrm{mmol} \mathrm{L}^{-1}\right)$ & $6.32 \pm 0.90^{\mathrm{a}}$ & $5.50 \pm 0.60^{\mathrm{ab}}$ & $5.00 \pm 0.03^{\mathrm{b}}$ \\
$\mathrm{TC}\left(\mathrm{mmol} \mathrm{L}^{-1}\right)$ & $1.22 \pm 0.05^{\mathrm{b}}$ & $1.50 \pm 0.10^{\mathrm{a}}$ & $1.30 \pm 0.12^{\mathrm{b}}$ \\
$\mathrm{TG}\left(\mathrm{mmol} \mathrm{L}^{-1}\right)$ & $0.82 \pm 0.02^{\mathrm{a}}$ & $0.70 \pm 0.02^{\mathrm{b}}$ & $0.90 \pm 0.05^{\mathrm{a}}$ \\
\hline
\end{tabular}

Data are shown as the mean \pm S.E.M. for eight values per group. Two groups were fed a hypocaloric diet supplemented with lupine (CR-Lupine) or Oats (CR-Oats). The third group was fed a CR diet without supplementation. The means with different superscripts $(\mathrm{a}$ and $\mathrm{b})$ were considered significantly different $(\mathrm{P}<$ $0.05)$ 
The CR-Oats and CR groups reduced more efficiently hypercholesterolemia (-13\% and $-19 \%$, respectively) than the CR-Lupine. Inversely, CR-Lupine acts considerably on hypertriglyceridemia (-22\% and $-15 \%$, respectively) compared to CR-Oats and CR groups.

\subsection{Serum and Lipoproteins Lipid Peroxidation}

In serum, TBARS concentrations were comparable in CR, CR-Lupine and CR-Oats groups (Table 2). In VLDL and $\mathrm{HDL}_{2}$ fractions, TBARS values showed no significant difference in the CR-Lupine group compared with the CR-Oats group. However, TBARS levels were respectively reduced by $26 \%$ and $49 \%$ in VLDL, $22 \%$ and $81 \%$ in $\mathrm{LDL}-\mathrm{HDL}_{1}$ and $65 \%$ and $58 \%$ in $\mathrm{HDL}_{2}$ in $\mathrm{CR}-\mathrm{Lupine}$ and $\mathrm{CR}-\mathrm{O}$ ats groups than the $\mathrm{CR}$ group.

Table 2. Thiobarbituric acid reactive substances (TBARS) contents in serum and lipoproteins in rats fed experimental diets for 28 days

\begin{tabular}{cccc}
\hline TBARS $\left(\mu \mathrm{mol} \mathrm{mL}{ }^{-1}\right)$ & CR & CR-Lupine & CR-Oats \\
\hline Serum & $24.84 \pm 4.17$ & $19.96 \pm 3.60$ & $17.84 \pm 3.50$ \\
Lipoproteins & & & \\
VLDL & $76.20 \pm 0.50^{\mathrm{a}}$ & $56.34 \pm 9.66^{\mathrm{b}}$ & $39.00 \pm 7.50^{\mathrm{b}}$ \\
LDL-HDL $_{1}$ & $24.01 \pm 0.70^{\mathrm{a}}$ & $18.60 \pm 1.61^{\mathrm{b}}$ & $4.55 \pm 1.18^{\mathrm{c}}$ \\
$\mathrm{HDL}_{2}$ & $18.02 \pm 1.50^{\mathrm{a}}$ & $6.21 \pm 0.30^{\mathrm{b}}$ & $7.49 \pm 0.78^{\mathrm{b}}$ \\
$\mathrm{HDL}_{3}$ & $20.62 \pm 0.40^{\mathrm{a}}$ & $14.64 \pm 0.47^{\mathrm{b}}$ & $23.90 \pm 3.16^{\mathrm{a}}$
\end{tabular}

Data are shown as the mean \pm S.E.M. for eight values per group. Two groups fed a hypocaloric diet supplemented with lupine (CR-Lupine) or Oats (CR-Oats). The third group was fed a CR diet without supplementation. The means with different superscripts $(\mathrm{a}, \mathrm{b}, \mathrm{c})$ were considered significantly different $(\mathrm{P}<$ $0.05)$.

$\mathrm{HDL}_{3}$-TBARS contents were respectively reduced by $39 \%$ and $29 \%$ in CR-Lupine compared to CR-Oats and CR groups.

\section{3 $H D L_{3}-U C, H D L_{3}-P L, H D L_{3}$-apo and $H D L_{2}-C E$ Contents}

In $\mathrm{CR}$-Lupine group compared with $\mathrm{CR}-\mathrm{Oats}$ and $\mathrm{CR}$ groups, $\mathrm{HDL}_{3}-\mathrm{UC}$ contents (acceptor of lecithin acyl group) had a tendency to decrease but not significantly (Table 3). Moreover, in CR-Lupine and CR-Oats groups, $\mathrm{HDL}_{3}$-PL levels (preferential substrate of LCAT) were respectively 2.1- and 1.8- fold lower compared to CR group. However, $\mathrm{HDL}_{3}$-apos concentrations were similar in the three groups. $\mathrm{HDL}_{2}-\mathrm{CE}$ concentrations (product of enzymatic reaction) were 1.8-fold elevated in CR-Lupine compared to CR-Oats and CR groups.

Table 3. LCAT and PON1 activities and $\mathrm{HDL}_{3}-\mathrm{UC}, \mathrm{HDL}_{3}-\mathrm{PL}, \mathrm{HDL}_{3}$-apo and $\mathrm{HDL}_{2}$-CE in rats fed experimental diets for 28 days

\begin{tabular}{cccc}
\hline & $\mathrm{CR}$ & CR-Lupine & CR-Oats \\
\hline LCAT activity $\left(\mathrm{nmoL}^{-1} \mathrm{~h}^{-1} \mathrm{~mL}^{-1}\right.$ serum $)$ & $106.93 \pm 8.05^{\mathrm{b}}$ & $139.07 \pm 5.70^{\mathrm{a}}$ & $103.60 \pm 1.54^{\mathrm{b}}$ \\
$\mathrm{HDL}_{3}-\mathrm{UC}\left(\mathrm{mmol} \mathrm{L}^{-1}\right)$ & $0.15 \pm 0.07$ & $0.10 \pm 0.01$ & $0.16 \pm 0.08$ \\
$\mathrm{HDL}_{3}-\mathrm{PL}\left(\mathrm{mmol} \mathrm{L}^{-1}\right)$ & $1.09 \pm 0.16^{\mathrm{a}}$ & $0.50 \pm 0.02^{\mathrm{c}}$ & $0.60 \pm 0.02^{\mathrm{b}}$ \\
$\mathrm{HDL}_{3}-\mathrm{Apos}\left(\mathrm{g} \mathrm{L}^{-1}\right)$ & $3.60 \pm 0.50$ & $4.10 \pm 0.20$ & $3.60 \pm 0.30$ \\
$\mathrm{HDL}_{2}-\mathrm{CE}\left(\mathrm{mmol} \mathrm{L}^{-1}\right)$ & $0.070 \pm 0.004^{\mathrm{b}}$ & $0.13 \pm 0.05^{\mathrm{a}}$ & $0.070 \pm 0.001^{\mathrm{b}}$ \\
\hline $\left.\mathrm{PON}_{(\mathrm{U} \mathrm{mL}}^{-1}\right)$ & & & \\
$\mathrm{Serum}_{\mathrm{HDL}}$ & $56.23 \pm 0.88^{\mathrm{c}}$ & $450 \pm 3^{\mathrm{a}}$ & $310 \pm 2^{\mathrm{b}}$ \\
$\mathrm{HDL}_{3}$ & $19.34 \pm 1.59^{\mathrm{c}}$ & $200.0 \pm 0.8^{\mathrm{a}}$ & $100.0 \pm 0.1^{\mathrm{b}}$ \\
\hline
\end{tabular}


Data are shown as the mean \pm S.E.M. for eight values per group. Two groups fed a hypocaloric diet supplemented with lupine (CR-Lupine) or Oats (CR-Oats). The third group was fed a CR diet without supplementation. The means with different superscripts $(\mathrm{a}, \mathrm{b}, \mathrm{c})$ were considered significantly different $(\mathrm{P}<$ $0.05)$.

\subsection{LCAT and PON1 Activities}

In CR-Lupine group compared to CR-Oats and CR groups, LCAT activity was 1.3 -fold higher (Table 3). Furthermore, PON1 activity was higher respectively 1.4- and 8-fold in serum, 2- and 10.3-fold in $\mathrm{HDL}_{2}$ and 4.5and 11-fold in $\mathrm{HDL}_{3}$.

Also, in CR-Oats group compared with the CR group, PON1 activity was enhanced in serum (5.5-fold), $\mathrm{HDL}_{2}$ (5-fold) and $\mathrm{HDL}_{3}$ (2.4-fold).

\section{Discussion}

Obesity has been developed in animals using different types of diets rich in carbohydrates, fats and calories. Rat models are therefore useful tools for inducing obesity as they will readily gain weight when fed high-fat diets (Noeman, Hamooda, \& Baalash, 2011). These models elucidate some underlying mechanisms contributing to the development of cardiovascular complications.

In the present study, obesity was induced in albino rats by feeding a high-fat diet. Obesity was induced within 12 weeks. The weight gained by rats fed a high-fat diet was significantly more important than that gained by those fed the normal diet (Louala, Hamza-Reguig, Benyahia-Mostefaoui, Boualga, \& Lamri-Senhadji, 2011).

Indeed, the obesity induced by feeding hypercaloric diets was accompanied by dyslipidemia which was characterized by increased TC and TG levels as compared with control values (Louala, Hamza-Reguig, Benyahia-Mostefaoui, Boualga, \& Lamri-Senhadji, 2011).

Some studies have indicated that feeding a high-fat diet is associated with hyperlipidemia, hyperinsulinemia, and glucose intolerance (Toshiharu, Issei, Hisashi, Nobuaki, \& Makoto, 1996; Festuccia, Laplante, Berthiaume, Gélinas, \& Deshaies, 2006).

Our results are in agreement with those of some studies which showed that a high-fat diet induced dyslipidemia characterized by an increase in serum levels of triacylglycerols, total cholesterol, LDL-C and VLDL-C and low levels of HDL-C as compared with control (Noeman, Hamooda, \& Baalash, 2011). Dyslipidemia in obesity may be due to the increased triacylglycerols content of the liver due to increased influx of excess non-essential fatty acids into the liver (Grundy, 2004).

Compared with the beginning of the experimentation, the three diets induced a reduction of the body weight. The proteins and the insoluble fibers of lupine and oats, by their satiating capacity, involved a weight loss (Lee et al., 2006).

At day 28, the three experimental diets induced a comparable effect on body weight reduction, which is in agreement with previous studies carried out in obese men under dietetic program based on leguminous plants and cereals with complete grains (Crujeiras, Parra, Abete, \& Martinez, 2007; Venn et al., 2013). In the same way, the incorporation of leguminous plants in a hypocaloric mode induced a significant weight loss compared to a hypocaloric mode without supplementation.

At the end of the experiment, oats supplementation in the hypocaloric diet showed a beneficial effect on glycemia compared with lupine supplementation. Nevertheless, the three diets reduced the hyperglycemia found at day 0 .

Caloric restriction improves glucose level and $\beta$ cell function in obese patients with type 2 diabetes (Malandrucco et al., 2012). However, experimental studies have shown that the products containing oats have a hypoglycemic effect by regulating the level of glucose in blood (Shen, Cai, Dong, \& Hu, 2011).

In a previous clinical study, data suggest that diet with legumes and/or whole grains has a hypocholesterolemic effect (Venn et al., 2013). After 28 days of experimentation, our results showed that the three restricted diets decreased hypercholesterolemia noted at day 0 and this reduction was noticeable in CR-Oats diet compared to $\mathrm{CR}$-Lupine. Oats are rich in soluble fiber, especially $\beta$-glucan. These fibers promote the fecal excretion of cholesterol by decreasing its synthesis by the liver, resulting in a reduction of blood cholesterol.

The mechanism of action suggested is in relation to the viscosity of $\beta$-glucan, which interferes with the reabsorption of bile acids, resulting in a decrease in plasma cholesterol. Moreover, whole grains high in viscous fiber (oats) decrease serum LDL-C (Harris \& Kris-Etherton, 2010). On the other hand, the three experimental 
diets induced a hypotriglyceridemic effect. This reduction is more marked with white lupine supplementation and is probably due to the soluble fibers present in larger quantity in lupine than in oats.

The metabolic disturbances (dyslipidemia and hyperglycemia) observed in obese rats at the beginning of the study were probably linked with an oxidative stress which is consequent to inadequate antioxidant defenses. This may possibly contribute to the additional progression of obesity related problems. Indeed, oxidative stress is highly correlated with a wide variety of inflammatory and metabolic disease states, including obesity (Reaven, Abbasi, \& McLaughlin, 2004). Moreover, it is highly correlated with cumulative damage in the body done by free radicals inadequately neutralized by antioxidants (Valdecantos, Pérez-Matute, \& Martínez, 2009).

Lipid peroxidation such as thiobarbituric acid reactive substances and hydroperoxides levels as well as markers of protein oxidation such as carbonyl proteins are markers of reactive oxygen species (ROS) oxidative damage (Olusi, 2002; Uzun, Konukoglu, Gelisgen, Zengin, \& Taskin, 2007).

Our results showed that TBARS concentration in VLDL, LDL-HDL $\mathrm{L}_{1}$ and $\mathrm{HDL}_{2}$ was significantly lower in both groups consuming the diets supplemented with legumes or cereals when compared to the CR diet without supplementation. This reduction may probably result from the presence of bioactive components in whole-grain cereal and legumes such as polyphenols and vitamin E (Oomah, Tiger, Olson \& Balasubramanian, 2006; Baudet, Daugareil, \& Ferrieres, 2009).

The hypotriglyceridemia found in the obese rats fed the CR diet supplemented with lupine may contribute to the improvement in the oxidant-antioxidant balance, suggesting that a decrease in the bioavailability of free fatty acids can decrease lipid peroxidation. Furthermore, the oxidative damage could be attenuated by an increase in antioxidant enzymes activities such as superoxide dismutase, catalase, glutathione S-transferase, and glutathione peroxidase which acts as free radical scavengers in conditions associated with oxidative stress.

LCAT is a major modulator of HDL metabolism. Our results showed that LCAT activity was higher in CR-Lupine group. Moreover, lupine supplementation in a calorie restricted diet decreased significantly $\mathrm{HDL}_{3}-\mathrm{PL}$ (the LCAT substrate) concentrations and increased $\mathrm{HDL}_{2}-\mathrm{CE}$ levels (product of enzymatic reaction) in obese rats.

Some reports have mentioned that LCAT enzyme may have a dual role in lipoprotein oxidation, whereby it acts in a dose-responsive manner as a potent prooxidant during VLDL oxidation, but as an antioxidant during LDL oxidation (McPherson, \& Young, McEneny, 2007). In CR-Lupine group compared with CR-Oats, LDL oxidation was higher despite enhanced LCAT activity. These findings suggest that lupine supplementation do not play an important protective role against LDL oxidation but it seems to prevent the antiatherogenic fraction (HDL) from free radical attacks. However, compared to CR diet without supplementation, lupine supplementation appears to act favorably on lipoperoxidation.

Paraoxonase (PON1) is another antioxidant enzyme closely associated with HDL. It is a calcium-dependent esterase which detoxifies lipid peroxides, and is widely distributed in many tissues. In human studies, higher PON1 activity is associated with a lower incidence of major cardiovascular events (Soran, Younis, Charlton-Menys, \& Durrington, 2009). Moreover, PON1 prevents the oxidation of the lipoproteins of weak density (LDL) (Podrez, 2010). Under oxidative stress (high-fat diet), PON1 may be inactivated by Sglutathionylation a redox regulatory mechanism characterized by the formation of mixed disulfide between a protein thiol and oxidized glutathione (Rozenberg, \& Aviram, 2006).

In obese rats, the supplementation of the CR diet with lupine increased PON1 activity in serum, $\mathrm{HDL}_{2}$ and $\mathrm{HDL}_{3}$ protecting thus LDL from oxidation and consequently seemed to reduce CVD. PON1 activity could be increased as a consequence of an improved synthesis of HDL secondary to enhanced LCAT activity.

\section{Conclusion}

In obese rats, lupine or oats supplementation in a hypocaloric diet have a positive impact on metabolic risk markers. Nevertheless, lupine compared to oats has a beneficial effect on hypertriglyceridemia and improves reverse cholesterol transport from peripheral tissues to the liver by increasing the activity of LCAT, and thus ensuring a fortification in $\mathrm{HDL}_{2}$ cholesteryl esters. This anti-atherogenic effect is particularly reinforced by the increased activity of HDL PON1 which protects it from oxidation.

\section{Acknowledgements}

This work was supported by the Algerian Ministry of Higher Education and Scientific Research (DG-RSDT, PNR project/47). 


\section{References}

Albers, J. J., Chen, C. H., Lacko, \& A. G. (1986). Isolation, characterization, and assay of lecithin-cholesterol acyltransferase. Methods Enzymology, 129, 763-783. http://doi.10.1016/B978-0-12-405883-5.09989-0

Archer, B., Johnson, S., Devereux, H., \& Baxter, A. (2004). Effect of fat replacement by inulin or lupin-kernel fibre on sausage patty acceptability, post-meal perceptions of satiety and food intake in men. British Journal of Nutrition, 91, 591-599. http://dx.doi.org/10.1079/BJN20031088

Baudet, M., Daugareil, C., \& Ferrieres, J. (2011). Cardiovascular disease prevention and life hygiene modifications. Annales de Cardiologie et d'Angéiologie, 99, 362-590. http://dx.doi.org/10.1016/j.ancard.2011.05.007

Bazzano, L. A., Thompson, A. M., Tees, M. T., Nguyen, C. H., \& Winham, D. M. (2009). Non-soy legume consumption lowers cholesterol levels: a meta-analysis of randomized controlled trials. Nutrition, Metabolism, and Cardiovasculaire diseases, 21, 94-103. http://dx doi.10.1016/j.numecd.2009.08.012

Bergouignan, A., Blanc, S., \& Simon, C. (2010). "Calories" and obesity Quantity or quality? Cahier de Nutrition et de Diététique, 45, 180-189. http://dx.doi.org/10.1016/j.cnd.2010.04.003

Burstein, M., Fine, A., Atger, V., Wirbel, E., \& Girard-Globa, A. (1989). Rapid method for isolation of two purified subfractions of high density lipoproteins by differential dextran sulfate-magnesium chloride precipitation. Biochimie, 71, 741-746. http://dx.doi.org/10.1016/0300-9084(89)90090-4

Burstein, M., Scholnick, H. R., \& Morfin, R. (1970). Rapid method for the isolation of lipoproteins from human serum by precipitation with polyanions. Journal of Lipid Research, 11, 583-595. http://www.jlr.org/content/11/6/583.

Council of European Communities. (1986). Council instructions about the protection of living animals used in scientific investigations. Off. J Eur Commun, 358, 1-28. 18.12.1986: L358; Corrigendum OJEC 05.05.1987: L117.

Crujeiras, A. B., Parra, D., Abete, I., \& Martinez, J. A. (2007). A hypocaloric diet enriched in legumes specifically mitigates lipid peroxidation in obese subjects. Free Radical Research, 41, 498-506. http://doi.10.1080/10715760601131935

Dullaart, R. P., Perton, F., Van der Klauw, M. M., Hillege, H. L., Sluiter, W. J., \& PREVEND Study Group (2010). High plasma lecithin: cholesterol acyltransferase activity does not predict low incidence of cardiovascular events: Possible attenuation of cardioprotection associated with high HDL cholesterol. Atherosclerosis, 208, 537-542. http:// dx.doi.org/10.1016/j.atherosclerosis.

Duncan, D. B. (1955). Multiple range and multiple range F-tests. Biometrics, 11, 41-42. http://dx.doi.org/10.2307/3001478

Festuccia, W. T., Laplante, M., Berthiaume, M., Gélinas, Y., \& Deshaies Y. (2006). PPAR gamma agonism increases rat adipose tissue lipolysis, expression of glyceride lipases, and the response of lipolysis to hormonal control. Diabetologia, 49, 2427-2436. http://dx.doi.org/10.1007/s00125-006-0336-y

Grundy, S. M. (2004). Obesity, Metabolic Syndrome, and Cardiovascular Disease. Journal of Clinical Endocrinology \& Metabolism, 89, 2595-2600. http://dx.doi.org/10.1210/jc.2004-0372

Harris, K. A., \& Kris-Etherton, P. M. (2010). Effects of whole grains on coronary heart disease risk. Current Atherosclerosis Reports, 12, 368-376. http://dx.doi.org/10.1007/s11883-010-0136-1

Hebert, J. R., Allison, D. B., Archer, E., Lavie, C. J., \& Blair, S. N. (2013). Scientific decision making, policy decisions, and the obesity pandemic Mayo Clinic Proceedings, 88, 593-604. http://dx.doi.org/10.1016/j.mayocp.2013.04.005

International Obesity Taskforce. (2012). Obesity: the Global Epidemic. International Association for the Study of Obesity. Retrieved from http://www.iaso.org/iot f/obesity/obesitytheglobalepidemic/.

Kuo, C. L., \& La Du, B. N. (1995). Comparison of purified and rabbit serum paraoxonases. Drug Metabolism and Disposition, 23, 935-944. http://dmd.aspetjournals.org/content/23/9/935

Lee, Y., Mori, T. A., Sipsas, S., Barden, A., Puddey, I. B., Burke, V., Hall, R. S., \& Hodgson, J. M. (2006). Lupin-enriched bread increases satiety and reduces energy intake acutely. American Journal of Clinical Nutrition, 84, 975-980. http://ajcn.nutrition.org/content/84/5/975.long

Louala, S., Hamza-Reguig, S., Benyahia-Mostefaoui, A., Boualga, A., \& Lamri-Senhadji, M. (2011). Effects of 
highly purified sardine proteins on lipid peroxidation and reverse cholesterol transport in rats fed a cholesterol-rich diet. Journal of Functional Foods, 3, 321-328. http://dx.doi.org/10.1016/j.jff.2011.07.002

Lowry, O. H., Rosebrough, N. J., Farr, A. L., \& Randall, R. J. (1951). Protein measurement with folin phenol reagent. Journal of Biological Chemistry, 193, 265-275. http://www.jbc.org/content/193/1/265.long

Maki, K. C., Beiseigel, J. M., Jonnalagadda, S. S., Gugger, C. K., Reeves, M. S., Farmer, M. V., ... Rains, T. M. (2011). Whole-grain ready-to-eat oat cereal, as part of a dietary program for weight loss, reduces low-density lipoprotein cholesterol in adults with overweight and obesity more than a dietary program including low-fiber control foods. Journal of American Dietetic Association, 110, 205-214. http://dx.doi.org/10.1016/j.jada.2009.10.037

Malandrucco, I., Pasqualetti, P., Giordani, I., Manfellotto, D., De Marco, F., Alegiani, F., ... Simona, F. (2012). Very-low-calorie diet: a quick therapeutic tool to improve $\beta$-cell function in morbidly obese patients with type 2 diabetes. The American Journal of Clinical Nutrition, 95, 609-613. http://dx.doi.org/10.3945/ajcn.111.023697

Martínez-Villaluenga, C., Frías, J., \& Vidal-Valverde, C. (2006). Functional lupin seeds (Lupinus albus and Lupinus luteus) after extraction of a-galactosides. Food Chemistry, 98, 291-299. http://dx.doi.org/10.1016/j.foodchem.2005.05.074

McPherson, P. A., Young, I. S., \& McEneny, J. A. (2007). Dual role for lecithin-cholesterol acyltransferase (EC 2.3.1.43) on lipoprotein oxidation. Free Radical Biology \& Medicine, 43, 1484-1493. http://dx.doi.org/10.1016/j.freeradbiomed.2007.08.007

Olusi, S. O. (2002). Obesity is an independent risk factor for plasma lipid peroxidation and depletion of erythrocyte cytoprotectic enzymes in humans. International journal of Obesity and Related Metabolic Disorder, 26, 1159-1164. http://dx.doi.org/10.1038/sj.ijo.0802066

Oomah, B. D., Tiger, N., Olson, M., \& Balasubramanian, P. (2006). Phenolics and antioxidative activities in narrow-leafed lupins (Lupinus angustifolius L.). Plant Foods for Human Nutrition, 61, 86-92. http://dx.doi.org/10.1007/s11130-006-0021-9

Podrez, E. A. (2010). Anti-oxidant properties of high-density lipoprotein and atherosclerosis. Clinical and $\begin{array}{lllll}\text { Experimental Pharmacology and } & \text { Physiology, }\end{array}$ http://dx.doi.org/10.1111/j.1440-1681.2010.05380.x

Poirier, P., Giles, T. D., Bray, G. A., Hong, Y., Stern, J. S., Pi-Sunyer, F. X., \& Eckel, R. H. (2006). Obesity and cardiovascular disease: pathophysiology, evaluation, and effect of weight loss. Arteriosclerosis Thrombosis and Vascular Biology, 26, 968-976. http://dx.doi.org/10.1161/01.ATV.0000216787.85457.f3

Quintanilha, A. T., Packer, L., Szyszlo, J. M., Racanelly, T. L., \& Davies, K. J. (1982). Membrane effects of vitamine E deficiency bioenergetic and surface charge density studies of skeletal muscle and liver mitochondria. Annals of the New York Academy of Sciences, 393, 32-37. http://dx.doi.org/10.1111/j.1749-6632.1982.tb31230.x

Reaven, G., Abbasi, F., \& McLaughlin, T. (2004). Obesity, insulin resistance, and cardiovascular disease. Recent Progress in Hormone Research, 59, 207-223. http://dx.doi.org/10.1210/rp.59.1.207

Rossmeislová, L., Mališová, L., Kračmerová, J., \& Stich, V. (2012). Adaptation of human adipose tissue to hypocaloric diet. Int $J$ Obes (Lond).

Rozenberg, O., \& Aviram, M. (2006). Glutathionylation regulates HDL-associated paraoxonase 1 (PON1) activity. Biochemical and biophysical research communications, 351, 492-498. http://dx.doi.org/10.1016/j.bbrc.2006.10.059

Shen, R. L., Cai, F. L., Dong, J. L., \& Hu, X. Z. (2011). Hypoglycemic effects and biochemical mechanisms of oat products on streptozotocin-induced diabetic mice. Journal of Agricultural and Food Chemistry, 59, 8895-8900. http://dx.doi.org/10.1021/jf200678q

Soran, H., Younis, N. N., Charlton-Menys, V., \& Durrington, P. (2009). Variation in paraoxonase-1 activity and $\begin{array}{lllll}\text { atherosclerosis. Current } & \text { Opinion in Lipidology, 20, } 274 .\end{array}$ http://dx.doi.org/10.1097/MOL.0b013e32832ec141

Toshiharu, A., Issei, T., Hisashi, S., Nobuaki, W., \& Makoto, O. (1996). High-fat hypercaloric diet induces obesity, glucose intolerance and hyperlipidemia in normal adult male Wistar rat. Diabetes Obesity and Metabolism, 11, 534-543. http://dx.doi.org/10.1016/0168-8227(96)01205-3 
Uzun, H., Konukoglu, D., Gelisgen, R., Zengin, K., \& Taskin, M. (2007). Plasma protein carbonyl and thiol stress before and after laparoscopic gastric banding in morbidly obese patients. Obesity Surgery, 17, 1367-1373. http://doi 10.1007/s11695-007-9242-8

Valdecantos, M. P., Pérez-Matute, P., \& Martínez, J. A. (2009). Obesity and oxidative stress: role of antioxidant supplementation. Revista de Investigación Clínica, 61, 127-139.

Venn, B. J., Perry, T., Green, T. J., Skeaff, C. M., Aitken, W., Moore, N. J., ... Williams, S. (2010). The Effect of Increasing Consumption of Pulses and Whole grains in Obese People: A Randomized Controlled Trial. Journal of the American College of Nutrition, 29, 365-372. http://dx.doi.org/10.1080/07315724.2010.10719853

Wells, H. F., \& Buzby, J. C. (2008). Dietary assessment of major trends in US food consumption, 1970-2005. Economic Information Bulletin; 33 Economic Research Service, US Department of Agriculture. Retrieved from http://www.ers.usda.gov/Publications/EIB33

\section{Copyrights}

Copyright for this article is retained by the author(s), with first publication rights granted to the journal.

This is an open-access article distributed under the terms and conditions of the Creative Commons Attribution license (http://creativecommons.org/licenses/by/3.0/). 